\title{
UVB (290-315 nm) inactivation of the SARS CoV-2 virus as a function of the standard UV index
}

\author{
Jay Herman ${ }^{1}$ (D) Rubén D. Piacentini ${ }^{2}$ \\ Received: 13 June 2021 / Accepted: 15 September 2021 / Published online: 4 November 2021 \\ (C) The Author(s) 2021
}

\begin{abstract}
The inactivation time for the SARS CoV-2 virus, mostly by a portion of UVB spectrum (290-315 nm) in sunlight, has been estimated using radiative transfer calculations and a relative wavelength sensitivity virus inactivation action spectrum $\mathrm{A}_{\mathrm{LS}}$. The action spectrum is adjusted for the SARS CoV-2 virus using a derived UV dose $D_{90}=3.2 \mathrm{~J} / \mathrm{m}^{2}$ for $90 \%$ inactivation to match laboratory results for the inactivation of SARS CoV-2 virus droplets on steel mesh. Estimation of the time for $90 \%$ inactivation $\mathrm{T}_{90}$ at a specific geographic location can be simplified using the commonly published or calculated UV index (UVI). The use of UVI has the advantage that information on the amount of ozone, the site altitude, and the degree of cloud cover are built into the published UVI calculation. Simple power-law $\mathrm{T}_{90}(\mathrm{UVI})=a \mathrm{UVI}^{b}$ fitting equations are derived that provide estimates of $\mathrm{T}_{90}(\mathrm{UVI})$ for 270 specific locations. Using the results from the 270 locations, a generalized latitude $\theta$ dependence is presented for the coefficients $a(\theta)$ and $b(\theta)$ that enables $\mathrm{T}_{90}(\theta, \mathrm{UVI})$ to be estimated for $60^{\circ} \mathrm{S} \leq \theta \leq 60^{\circ} \mathrm{N}$ and for noon and $2 \mathrm{~h}$ around local solar noon.
\end{abstract}

Keywords COVID-19 $\cdot$ SARS-CoV-2 $\cdot$ Inactivation $\cdot$ Radiative transfer $\cdot$ Ozone $\cdot$ UVB $\cdot$ UVC $\cdot$ UV Index

\section{Introduction}

The $90 \%$ inactivation time $\mathrm{T}_{90}$ of the SARS CoV-2 virus by $254 \mathrm{~nm}$ UVC light has been estimated from laboratory experiments (Anderson et al. 2013; Bedell et al. 2016; Heßling et al. 2020; Lytle and Sagripanti 2005; Sagripanti and Lytle 2020; Kowalski et al. 2009; Kowalski 2009) along with significant but reduced inactivation rates for exposure to 290 to $315 \mathrm{~nm}$ UVB light (Eisenstark 1987; Nelson et al. 2018; RatnesarShumate et al. 2020; Herman et al. 2020a). This paper will briefly examine the use of the UV index (UVI = erythemal irradiance in $\mathrm{mW} / \mathrm{m}^{2}$ divided by $25 \mathrm{~mW} / \mathrm{m}^{2}$ ) to estimate $\mathrm{T}_{90}(\mathrm{UVI})$ for the latitude range $60^{\circ} \mathrm{S} \leq \theta \leq 60^{\circ} \mathrm{N}$. The advantage of using the UVI is that the index is forecast and

Jay Herman

Herman@umbc.edu

Rubén D. Piacentini

ruben.piacentini@gmail.com

1 University of Maryland Baltimore County JCET, Baltimore, MD, USA

2 Institute of Physics Rosario, CONICET - National University of Rosario and Technological Institute of Design and Innovation, Faculty of Exact Sciences, Engineering and Surveying, National University of Rosario, Rosario, Argentina published daily for many locations around the world (Heckman et al. 2019), so that $T_{90}(U V I)$ is a useful tool to estimate ultraviolet germicidal irradiance (UVGI) viral inactivation in the UVB range. In addition, the UVI measurements or estimates already contain information on ozone amount, aerosol amount, cloud cover, and altitude for each site needed for the estimate of $\mathrm{T}_{90}$ (see ESM Electronic Supplemental Material or https://avdc.gsfc.nasa.gov/pub/DSCOVR/ JayHerman/CoV_vs_UVI/ ).

\section{Inactivation time $\mathrm{T}_{\mathbf{9 0}}(\mathrm{UVI})$ of SARS CoV-2 by UVGI}

In the paper by Herman et al. (2020a), $\mathrm{T}_{90}$ was calculated from a derived relative wavelength sensitivity action spectrum for virus inactivation by UVC and UVB exposure (Lytle and Sagripanti 2005). This action spectrum $A_{L S}(\lambda$ was used to derive the equivalent $254 \mathrm{~nm}$ inactivation parameter $\mathrm{D}_{90}=3.2$ $\mathrm{J} / \mathrm{m}^{2}$ (Herman et al. 2020a) that gives approximately the same results as the laboratory inactivation measurements for SARSCoV-2 on steel mesh exposed to simulated sunlight (RatnesarShumate et al. 2020). The amount of irradiance at the Earth's surface $F_{O}(\lambda)\left(\mathrm{mW} / \mathrm{m}^{2}\right)$ needed to estimate $T_{90}$ in the critical 290 to 315 UVB range was calculated for over 270 locations (Herman et al. 2020b) with their elevations plus the daily 
effects of cloud and aerosol cover, ozone amounts all obtained from the OMI (Ozone Monitoring Instrument) satellite data record (Schenkeveld et al. 2017). The key equation linking the laboratory results with inactivation time is given by Eqs. 1 and 2.

$$
\frac{\mathbf{N}}{\mathbf{N}_{\mathbf{0}}}=\mathbf{e}^{-\mathbf{k D}}
$$

The dose $\mathrm{D}=\mathrm{D}_{90}$ is a time accumulated irradiance exposure $\left(\mathrm{J} / \mathrm{m}^{2}\right)$ such that the survival fraction $\mathrm{N} / \mathrm{N}_{0}=0.1$, where $\mathrm{N}$ $=$ the number of virus particles left after exposure $\mathrm{D}\left(\mathrm{J} / \mathrm{m}^{2}\right)$ to UVB starting with $\mathrm{N}_{\mathrm{O}}$ particles.

$\mathrm{T}_{90}$ is then calculated from

$$
\mathrm{T}_{90}=\frac{\mathrm{D}_{90}}{\int_{290}^{320} \mathrm{~A}_{\mathrm{LS}}(\lambda) \mathrm{F}_{\mathrm{o}}(\lambda) \mathrm{d} \lambda}(\text { Seconds })
$$

$F_{O}(\lambda)$ and $F_{O}(\lambda) A_{L S}(\lambda)$ are calculated from the publicly available tropospheric ultraviolet and visible (TUV) scalar radiative transfer code (Madronich 1993, 1995; Herman et al. 2020b) https://www2.acom.ucar.edu/modeling/tuvdownload for every day of each year for 16 years from 2005 to 2020. Recent inactivation measurements of SARS CoV-2 exposed to sunlight for virus containing droplets onto a stainless-steel wire mesh (Ratnesar-Shumate et al. 2020) led to an estimate of $\mathrm{D}_{90}=3.2 \mathrm{~J} / \mathrm{m}^{2}$ (Herman et al. 2020a), which is used for the analysis presented here. If different values for $\mathrm{D}_{90}$ are used, the results are proportionately scaled. The time $t$ for decreased survival fraction can easily be estimated because of the exponential relationship in Eq. 1. That is, if $\mathrm{N} / \mathrm{N}_{\mathrm{O}}=0$. 001, then $\mathrm{T}_{99.9}=3 \mathrm{~T}_{90}$.

Applications of Eqs. 1 and 2 for three specific sites are shown in Figs. 1 to 3. Figure 1 outlines the method of finding the relationship between the calculated $\mathrm{T}_{90}$ and UVI time series. The $\mathrm{T}_{90}$ time series for Buenos Aires, Argentina (Fig. 1a) shows the seasonal dependence with a minimum in summer and a maximum in winter in a range from 3.4 to $50 \mathrm{~min}$ for most days of the year. Values can exceed $50 \mathrm{~min}$ when it is exceptionally cloudy. The strong seasonal dependence of the UVI (Fig. 1b) anti-correlates well with $\mathrm{T}_{90}$ so that high values of UVI correspond to low values of $\mathrm{T}_{90}$. When the $\mathrm{T}_{90}$ is plotted against UVI (Figs. 1c and d), the resulting distribution of points closely resembles a power-law function (Eq. 3).

$\mathbf{T}_{\mathbf{9 0}}=\mathbf{a}(\mathbf{U V I})^{\mathbf{b}}$

The coefficients $a$ and $b$ in Eq. 3 can be derived using either of two methods. First, is a fitting error minimization procedure applied directly to the data points shown in Fig. 1d (red) or, second, derived from a linear fit (blue, Eq. 4) shown in the Log-Log plot of Fig. 1c. The linear fit for the blue curve LogLog fit yields a better result passing closer through the center of the data points for UVI $>2$ than the direct minimization fit that is above the data points (Fig. 1d).

$$
\text { T }_{\text {90-BA }}=72.51(\text { UVI })^{-1.1559}(\log -\log \text { fit })
$$

A second example $\mathrm{T}_{90-\mathrm{MAN}}$ is shown for Manhattan, New York City (Latitude $40.8^{\circ} \mathrm{N}$ ), where the fit from the Log-Log linear fit method (Eq. 5) also produces better results for UVI > 2 than the direct-fit method (Fig. 2).

$$
\mathrm{T}_{90-\text { Man }}=87.67(\text { UVI })^{-1.2085}(\log -\text { Log fit })
$$

A third example is shown for equatorial data from Quito, Ecuador (latitude $0.18^{\circ} \mathrm{S}$ ) where there is almost no seasonal dependence in the $\mathrm{T}_{90}$ time series (Fig. 3a), but with a weak biennial signal suggested by the black-line Loess $(0.2)$ fit, (Cleveland 1979; Cleveland 1981). For this case, the direct fit and the Log-Log linear fit are indistinguishable. The time series and correlation plots presented from these 3 sites are typical for all 270 sites (220 land sites and 50 ocean sites) considered (ESM Appendix Table 1). The Pacific Ocean sites are located along lines of longitude $-60^{\circ} \leq \theta \leq 60^{\circ}$ at $179^{\circ} \mathrm{W}$ and the Atlantic Ocean sites at $30^{\circ} \mathrm{W}$. Another 25 land sites (labelled SH_NH) are located along $60^{\circ} \mathrm{W}$ from $-60^{\circ} \leq \theta \leq$ $60^{\circ}$. The remaining 195 land sites are mostly large cities, $-60^{\circ}$ $\leq \theta \leq 60^{\circ}$.

$$
\text { T90-Quito }_{\text {90 }}=47.84(\text { UVI })^{-1.004}(\log -\text { Log fit })
$$

Figure 4 shows two high latitude sites that do not have many values of high UVI. Helsinki, Finland, at $60.17^{\circ} \mathrm{N}$ rarely has UVI $>6$ and Ushuaia, Argentina, $54.8^{\circ} \mathrm{S}$ only has a few points greater than UVI $=8$ that are associated with exceptionally low ozone values when the Antarctic ozone hole passes over Ushuaia.

ESM Table S1 shows the results for the coefficients $a$ and $b$ (Eq. 3) based on the Log-Log linear fit method for the 270 selected locations $60^{\circ} \mathrm{S}$ to $60^{\circ} \mathrm{N}$ and various longitudes covering the Earth including the Atlantic and Pacific Ocean locations. When sorted by latitude, there is a clear latitudinal dependence of $\mathrm{T}_{90}(\theta)$ vs $\mathrm{UVI}(\theta)$ and in $a(\theta)$ and $b(\theta)$ (Figs. 5 and 6).

The coefficients $a(\theta)$ and $b(\theta)$ from ESM Appendix Table 1 are plotted vs latitude $-60^{\circ} \leq \theta \leq 67^{\circ}$ for solar time $t=12: 00$ (Fig. 5). The shape of the $a(\theta)$ and $b(\theta)$ curves at $\theta>40^{\circ} \mathrm{N}$ and $\mathrm{S}$ have no physical meaning but are an artifact of fitting UVI data with increased scatter from higher ozone values and increased amounts of cloud cover compared to sites at lower latitudes.

The values of $\mathrm{T}_{90}$ obtained from Eq. 7 are longitude averages of the considered locations from ESM Appendix Table 1 that give an estimate of the inactivation time in minutes for a given value of UVI. If the UVI is only provided for $t=12: 00$ noon conditions, estimates for other times of the day can be 

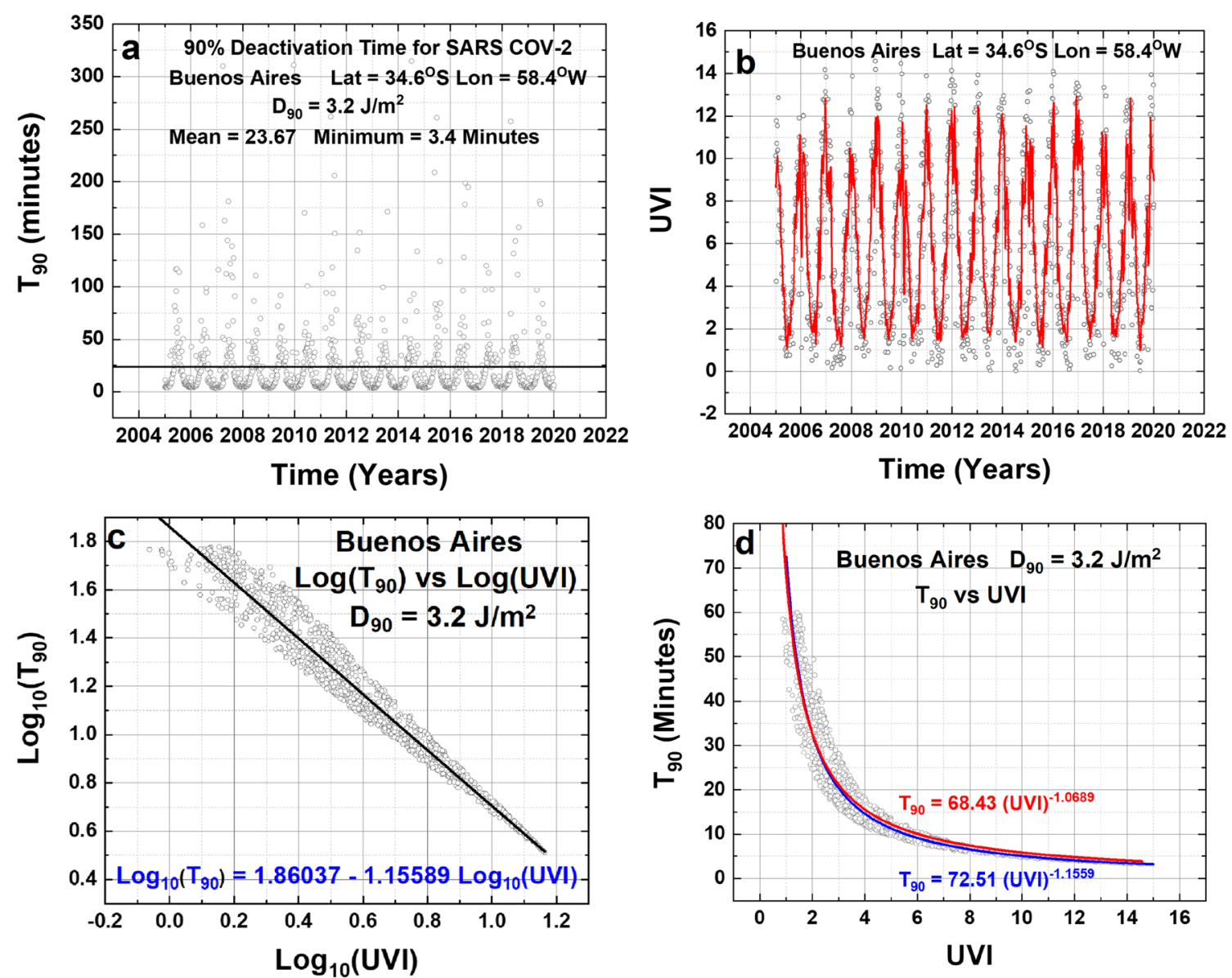

Fig. 1 a Calculated T90 time series for Buenos Aires, Argentina. b UVI time series. c Log-Log scale plot of T90 vs UVI. d Linear scale plot of T90 vs UVI containing the direct fit (red line) and the Log-Log fit (blue line). The mean inactivation time is 23.67 min, and the minimum is 3.4 min.

obtained (Herman et al. 2020a) if the atmospheric conditions are approximately the same as local noon (see Figs. 6 and 7).

$\mathbf{T}_{\mathbf{9 0}}(\theta)=\mathbf{a}(\theta)(\mathbf{U V I})^{\mathbf{b}(\theta)}$
Figure 6 shows the results of using Eq. 7 to estimate $T_{90}$ as a function of latitude $\theta$ (degrees) for specified values of UVI estimated at 12:00 local solar time. $\mathrm{T}_{90}(\theta)$ calculated as in Fig. 6 differs from specific site values because the fitting coefficients, $a(\theta)$ and $b(\theta)$, are a least-squares longitude-latitude fit
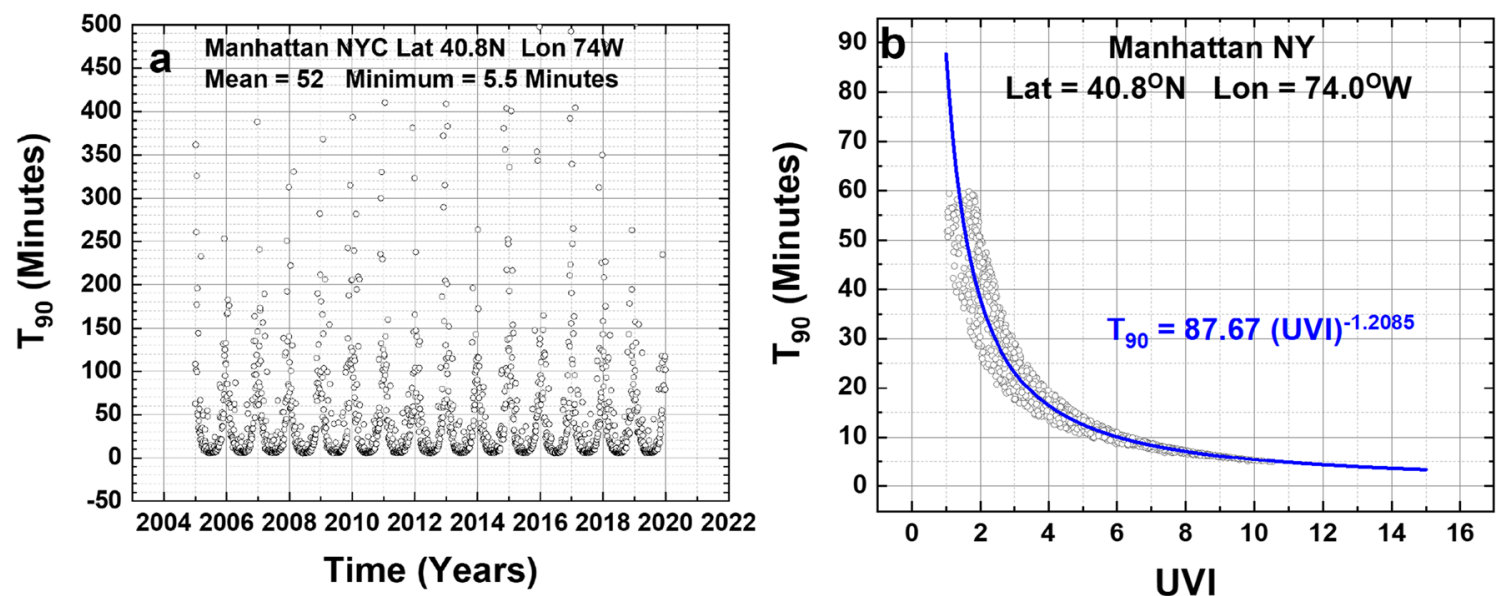

Fig. 2 a $\mathrm{T}_{90}$ time series. b $\mathrm{T}_{90}$ vs UVI for Manhattan, New York City, for $\mathrm{D}_{90}=3.2 \mathrm{~J} / \mathrm{m}^{2}$. Mean $=52$ min with a summer minimum of $5.5 \mathrm{~min}$. b Power law fit to $\mathrm{T}_{90}(\mathrm{UVI})$ 

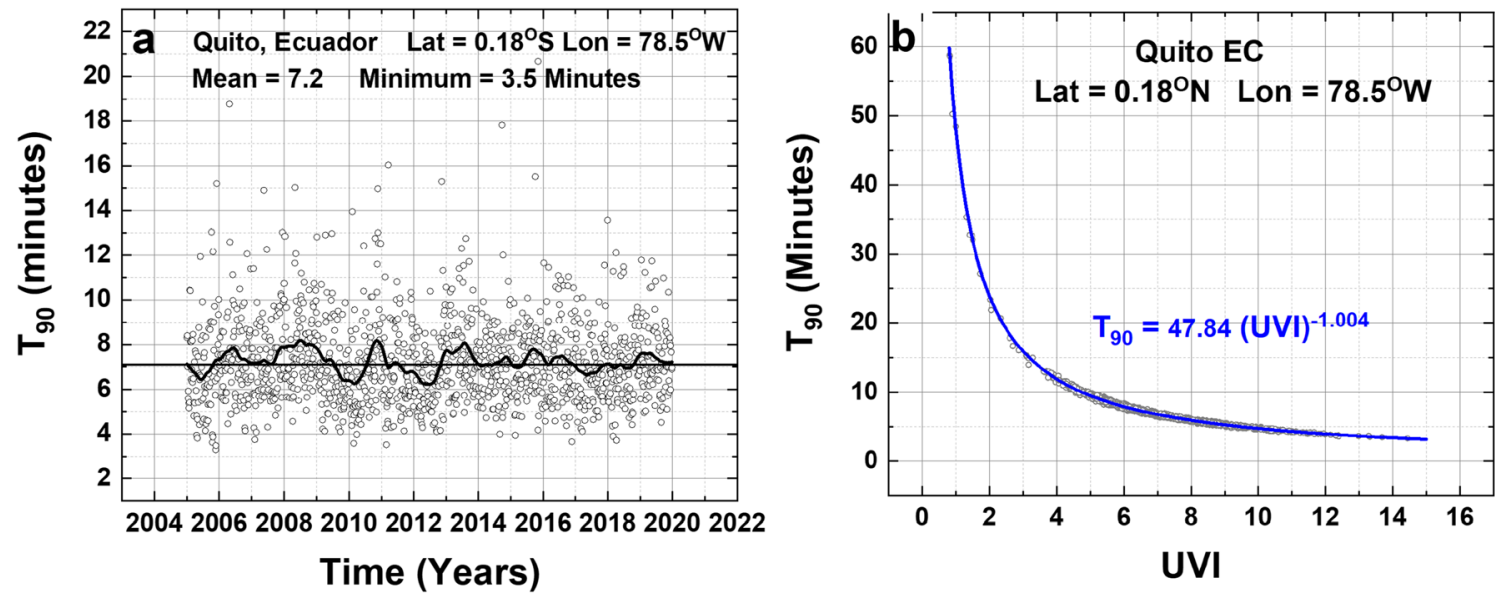

Fig. 3 a $\mathrm{T}_{90}$ time series. $\mathbf{b} \mathrm{T}_{90}$ vs UVI for Quito, Ecuador, for $\mathrm{D}_{90}=3.2 \mathrm{~J} / \mathrm{m}^{2}$. Mean $=7.2$ min with an exceptionally clear-sky minimum of $3.5 \mathrm{~min}$ that occurs occasionally during the 16 years. The black line is a Loess $(0.2)$ fit to the $\mathrm{T}_{90}$ data. b Power law fit to $\mathrm{T}_{90}(\mathrm{UVI})$ data
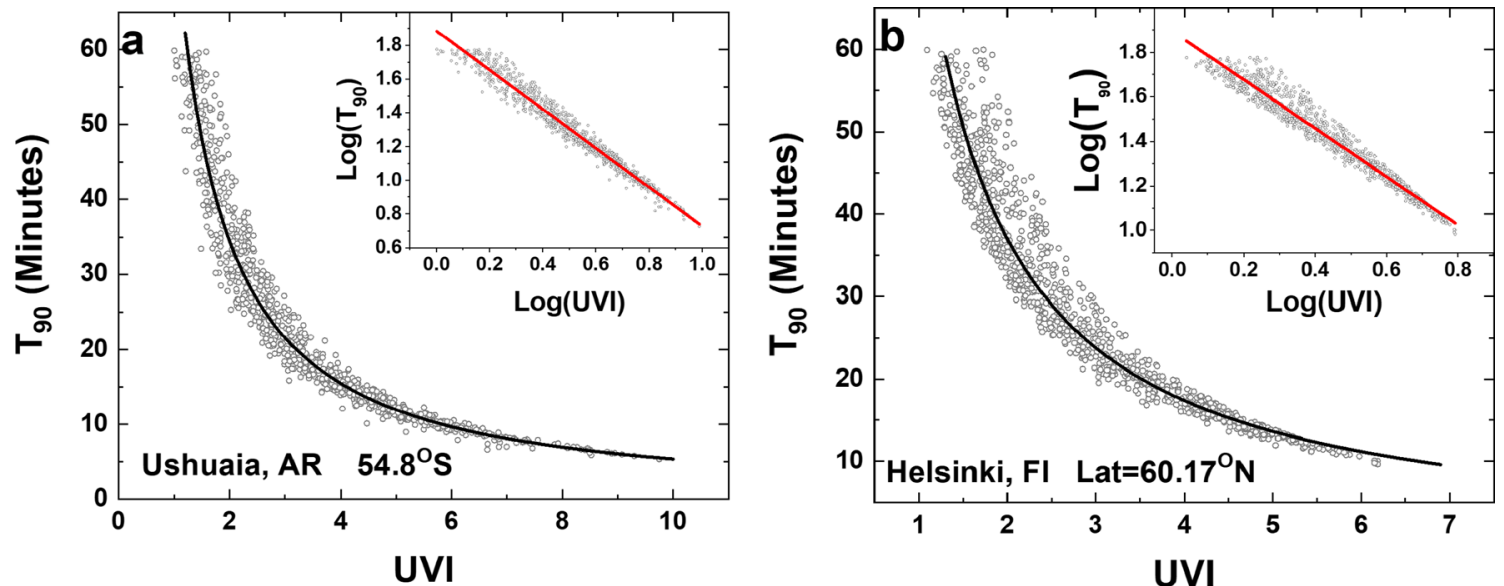

Fig. 4 Two high latitude sites. a Ushuaia, Argentina, and b Helsinki, Finland. The solid lines are from the fitting parameters $a$ and $b$ in ESM Appendix Table 1. $\mathrm{T}_{90-\mathrm{Ush}}=76.89(\mathrm{UVI})^{-1.1578}$ and $\mathrm{T}_{90-\mathrm{Hel}}=78.66(\mathrm{UVI})^{-1.0890}$
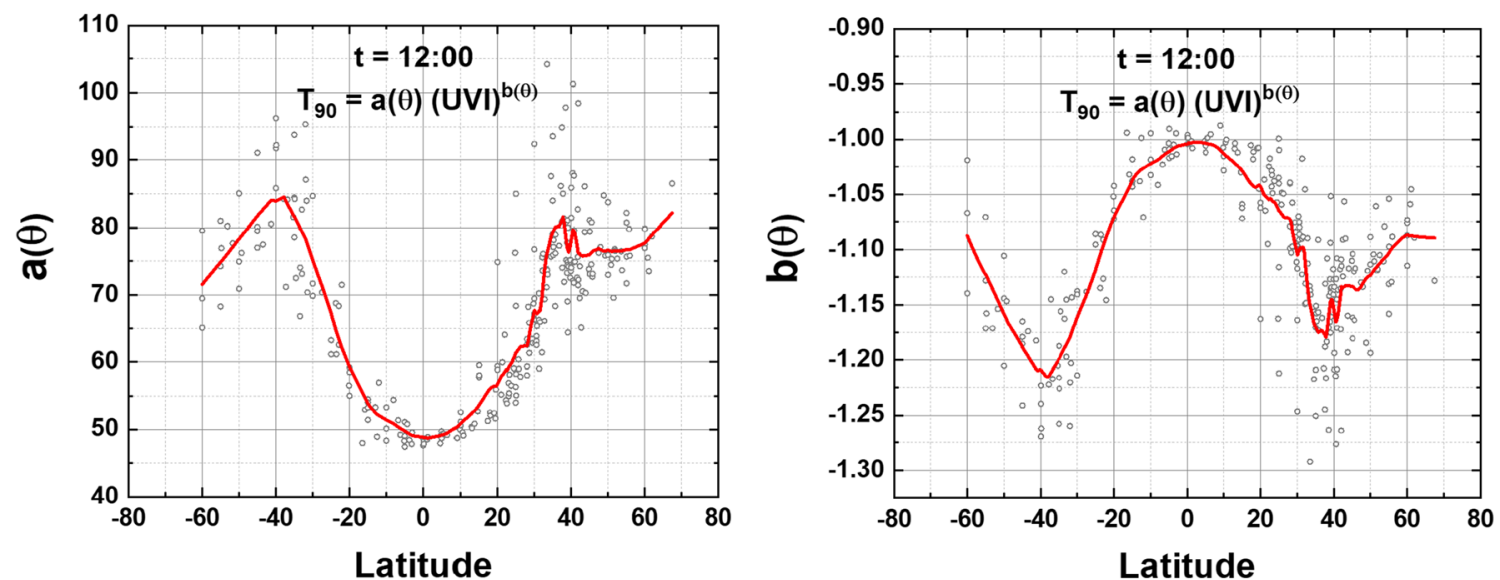

Fig. 5 Graph of fitting coefficients $a(\theta)$ and $b(\theta)$ obtained from each location in ESM Appendix Table 1 . The solid lines are a Loess $(0.1)$ fit to $a(\theta)$ and $b(\theta)$ for local solar time $t=12: 00$ 


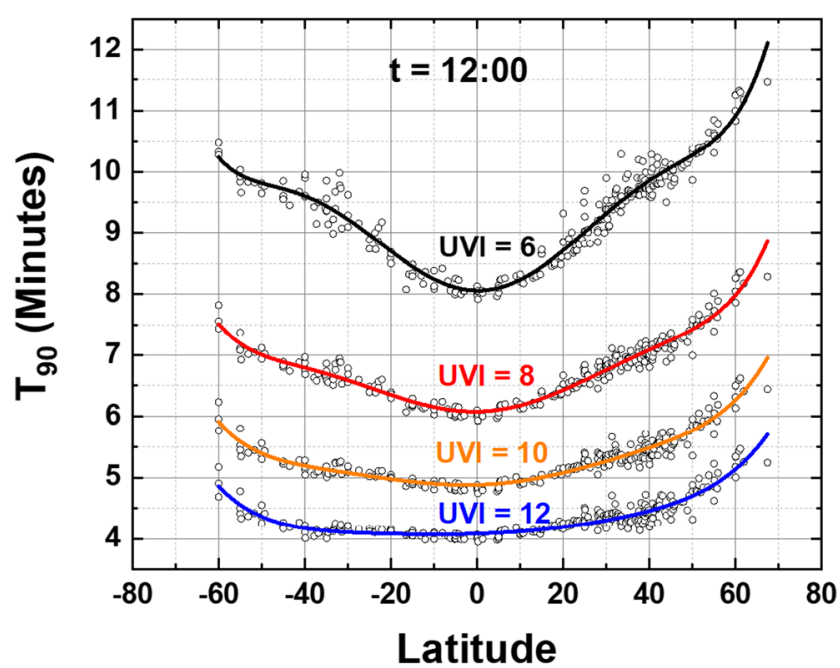

Fig. 6 Application of ESM Appendix Table 2 (solid lines) with Eq. 7 to estimate $\mathrm{T}_{90}(\theta)$ for $\mathrm{UVI}=6,8,10$, and 12 for local solar time $t=12: 00$. The circles are sites from ESM Appendix Table 1

from the $60^{\circ} \mathrm{S}$ to $67^{\circ} \mathrm{N}$ tabulated sites (Fig. 5) with the solid lines a Loess $(0.1)$ fit to the data points.

The different latitude dependent shapes of $a(\theta), b(\theta)$, and $\mathrm{T}_{90}(\theta, \mathrm{UVI})$ for different solar times $t$ are partly an effect of the solar zenith angle SZA and $\mathrm{O}_{3}$ amounts and its differential effect on $\mathrm{A}_{\mathrm{LS}}(\lambda) \mathrm{F}_{0}(\lambda), 290<\lambda<315 \mathrm{~nm}$, compared to the action spectrum for erythemal irradiance $\mathrm{A}_{\text {ery }}(\lambda) \mathrm{F}_{0}(\lambda), 300<\lambda<$ $400 \mathrm{~nm}$ (McKinlay and Diffey 1987; Webb et al. 2011). There are different atmospheric absorption amounts for short wavelength UVB (290-315 nm) compared to UVI (300-400 nm) penetrating to the Earth's surface. The latitude dependence of $\mathrm{T}_{90}$ and UVI are different from equatorial zone latitudes, because of smaller solar zenith angle SZA and lower equatorial zone total column ozone TCO, compared to higher latitudes because of increasing TCO and SZA. In addition, Figs. 6 and 7 combine different seasons, altitudes, and different cloud conditions in each $\mathrm{T}_{90}(\theta, \mathrm{UVI})$ curve, since they are derived from a longitude average of entries in ESM Appendix Table 1. For a particular location, an estimate of $\mathrm{T}_{90}(\mathrm{UVI})$ can be found using the specific $a(\theta)$ and $b(\theta)$ from ESM Appendix Table 1 or using one nearby the desired location.

Figure 7 shows the effect of different local solar times (13:00 and 14:00) on the value of $T_{90}(\mathrm{UVI})$ assuming that the atmosphere is the same as at noon. The graphs also apply at 10:00 and 11:00 as a function of time from local solar noon.

At the equator for a site with $\mathrm{UVI}=10$ at noon $\mathrm{T}_{90}=5 \mathrm{~min}$. Later in the day, say 14:00 h, if UVI decreases to UVI $=6$, then and $\mathrm{T}_{90}=9 \mathrm{~min}$. UVI $=6$ would be a clear bright-sun day in March or September at low altitude mid-latitude sites such as in Washington, DC, Rome, Italy, or Lauder, NZ.

\section{Summary}

A method for estimating the $90 \%$ inactivation time $\mathrm{T}_{90}(\mathrm{UVI})$ for SARS-CoV-2 virus from measured or calculated UV index UVI has been derived for 270 specific sites (ESM Appendix Table 1) in terms of power law $\mathrm{T}_{90}(\mathrm{UVI}, \theta)=a(\theta)(\mathrm{UVI})^{b(\theta)}$ approximations. The Log-Log plot preferred method for determining the coefficients $a(\theta)$ and $b(\theta)$ is presented for three mid-latitude sites, Buenos Aires $\left(34.6^{\circ} \mathrm{S}, 54.4^{\circ} \mathrm{W}\right)$, Manhattan, New York City $\left(40.8^{\circ} \mathrm{N}, 74^{\circ} \mathrm{W}\right)$, an equatorial site Quito, Ecuador $\left(0.18^{\circ} \mathrm{S}\right.$, $\left.78.5^{\circ} \mathrm{W}\right)$, and two high latitude sites, Helsinki $\left(60.2^{\circ} \mathrm{N}, 24.9^{\circ} \mathrm{E}\right)$ and Ushuaia, Argentina $\left(50.80^{\circ} \mathrm{S}, 68.30^{\circ} \mathrm{W}\right)$. All five sites have $\mathrm{T}_{90}$ anti-correlated with UVI, and correlation plots of $\mathrm{T}_{90} \mathrm{Vs}$ UVI suggest that a power-law fit is appropriate over a wide range of latitudes. A summary of the latitude $\theta$ dependence of the coefficients $a(\theta), b(\theta)$, and $\mathrm{T}_{90}(\theta)$ is presented based on the fitting results for 270 specific sites in ESM Appendix Table 1. $T_{90}(\theta$, $\mathrm{UVI}, t$ ) is shown for 4 different values of $\mathrm{UVI}$ (UVI $=6,8,10$, and 12) typical of summer $t=12: 00$ values for mid- and lowlatitude sites. $\mathrm{T}_{90}(\theta, \mathrm{UVI}, t)$ was estimated for additional solar times, 13:00 and 14:00 $\mathrm{h}$ assuming the atmosphere is the same as
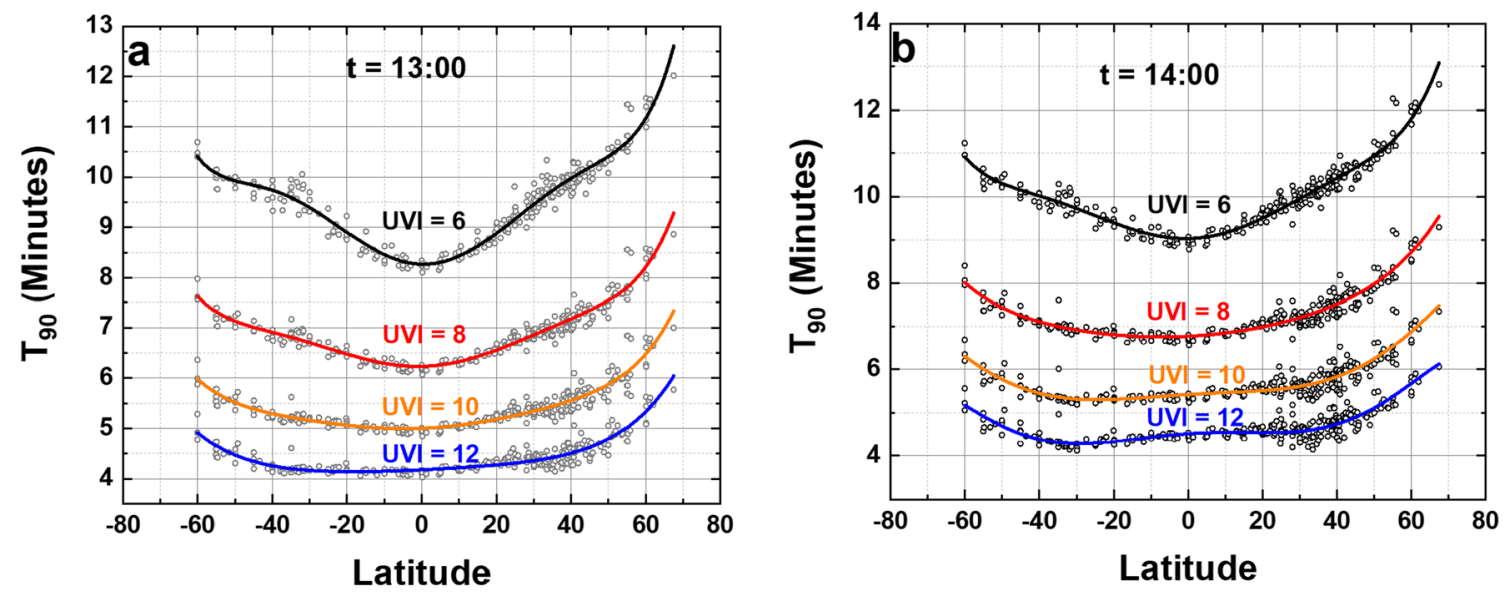

Fig. 7 Same as Fig. 6 except for different times of day, $t=13: 00$ to 14:00 local solar time. For the solid lines, see ESM Appendix Tables 3 and 4, for the fitting coefficients for the solid lines 
at 12:00. $\mathrm{T}_{90}(\theta, \mathrm{UVI}, t)$ for morning values are the same as afternoon values relative to their time difference from noon 10:00 and 11:00 h. Intermediate values of $\mathrm{T}_{90}(\theta, \mathrm{UVI}, t)$ can easily be estimated. The graphs and ESM Appendix Table 1 provide a quick method to estimate $\mathrm{T}_{90}$, if the commonly published UVI is known or calculated.

Supplementary Information The online version contains supplementary material available at https://doi.org/10.1007/s11869-021-01099-3.

Acknowledgements The authors would like to thank and acknowledge the support of the DSCOVR project and the OMI science team for the OMI satellite project for making OMI data freely available.

Author contribution Jay Herman is responsible for all of the calculations, figures, and large portions of the text. Rubén D Piacentini suggested the possible relationship between UVI and $\mathrm{T}_{90}$ and helped with portions of the text.

Funding This research is supported by the DSCOVR/EPIC NASA project under UMBC task 00011511.

Availability of data and material All data used in this study are available in stated public archives, listed references, or included explicitly in the study. OMI data used in this study are available from referenced publications and https://avdc.gsfc.nasa.gov/pub/data/satellite/Aura/OMI/V03/ L2OVP/OMTO3/.

Code availability The radiative transfer code TUV is publicly available as described in the references. Graphics and analysis use OriginLab Origin Pro software.

\section{Declarations}

Ethics approval There are no ethics issues in this study.

Conflict of interest The authors declare no competing interests.

Open Access This article is licensed under a Creative Commons Attribution 4.0 International License, which permits use, sharing, adaptation, distribution and reproduction in any medium or format, as long as you give appropriate credit to the original author(s) and the source, provide a link to the Creative Commons licence, and indicate if changes were made. The images or other third party material in this article are included in the article's Creative Commons licence, unless indicated otherwise in a credit line to the material. If material is not included in the article's Creative Commons licence and your intended use is not permitted by statutory regulation or exceeds the permitted use, you will need to obtain permission directly from the copyright holder. To view a copy of this licence, visit http://creativecommons.org/licenses/by/4.0/.

\section{References}

Anderson DJ, Gergen MF, Smathers E, Sexton DJ, Chen LF, Weber DJ, Rutala WA (2013) Decontamination of targeted pathogens from patient rooms using an automated ultraviolet-C-emitting device. Infect Cont Hosp Ep 34(5):466-471. https://doi.org/10.1086/670215

Bedell K, Buchaklian A, Perlman S (2016) Efficacy of an automated multiple emitter whole-room ultraviolet-C disinfection system against coronaviruses MHV and MERS-CoV. Infect Cont Hosp Ep 37(5):598-599. https://doi.org/10.1017/ice2015348

Cleveland WS (1979) Robust locally weighted regression and smoothing scatter plots. J Am Stat Assoc 74:829-836. https://doi.org/10.1080/ 01621459197910481038

Cleveland WS (1981) LOWESS: A program for smoothing scatterplots by robust locally weighted regression. Am Stat 35(1):54 JSTOR 2683591. https://doi.org/10.2307/2683591

Eisenstark A (1987) Mutagenic and lethal effects of near-ultraviolet radiation $(290-400 \mathrm{~nm})$ on bacteria and phage. Environ Mol Mutagen 10:317-337. https://doi.org/10.1002/em2850100311

Heckman CJ, Liang K, Riley M (2019) Awareness, understanding, use, and impact of the UV index: a systematic review of over two decades of international research. Prev Med. 123:71-83. https://doi. org/10.1016/j.ypmed.2019.03.004

Herman JR, Biegel B, Huang L (2020a) Inactivation times from 290-315 nm UVB in sunlight for SARS coronaviruses $\mathrm{CoV}$ and $\mathrm{CoV}-2$ using OMI Satellite Data for the Sunlit Earth. Air Qual Atmos Health, AIRQ-D-20-00395 14:217-233. https://doi.org/10.1007/s11869020-00927-2

Herman J, Cede A, Huang L, Ziemke J, Kowalewski M, Blank K (2020b) Global distribution and 14-year changes in erythemal irradiance, UV atmospheric transmission, and total column ozone 2005-2018 estimated from OMI and EPIC Observations. Atmos Chem and Physics 20:8351-8380. https://doi.org/10.5194/acp-20-8351-2020

Heßling M, Hönes K, Vatter P, Lingenfelder C (2020) Ultraviolet irradiation doses for coronavirus inactivation-review and analysis of coronavirus photoinactivation studies. GMS Hyg Infect Control 15: Doc08. https://doi.org/10.3205/dgkh000343

Kowalski W (2009) Ultraviolet germicidal irradiation handbook, UVGI for air and surface disinfection. Springer, Dordrecht. https://doi.org/ 10.1007/978-3-642-01999-9

Kowalski W, Bahnfleth W, Hernandez M (2009) A genomic model for predicting the ultraviolet susceptibility of viruses. IUVA News 11:15-24

Lytle CD, Sagripanti J-L (2005) Predicted inactivation of viruses of relevance to biodefense by solar radiation. J Virol 79:14244-14252. https://doi.org/10.1128/JVI792214244-142522005

Madronich S (1993) The atmosphere and UV-B radiation at ground level. In: Björn LO, Young AR (eds) Environmental UV photobiology. Plenum, New York, pp 1-39

Madronich S (1995) The radiation equation. Nature 377:682-683

McKinlay A, Diffey B (1987) A reference action spectrum for ultraviolet induced erythema in human skin. CIE J 6:17-22

Ratnesar-Shumate S, Williams G, Green B, Krause M, Holland B, Wood S, Bohannon J, Boydston J, Freeburger D, Hooper I, Beck K, Yeager J, Altamura LA, Biryukov J, Yolitz J, Schuit M, Wahl V, Hevey M, Dabisch P (2020) Simulated sunlight rapidly inactivates SARS-CoV-2 on surfaces. J Infect Dis 222(2):214-222. https://doi. org/10.1093/infdis/jiaa274

Sagripanti JL, Lytle CD (2020) Estimated inactivation of coronaviruses by solar radiation with special reference to COVID-19. Photochem Photobiol 96(4):731-737. https://doi.org/10.1111/php.13293

Schenkeveld VME, Jaross G, Marchenko S, Haffner D, Kleipool QL, Rozemeijer NC, Veefkind JP, Levelt PF (2017) In-flight performance of the Ozone Monitoring Instrument. Atmos Meas Tech 10:1957-1986. https://doi.org/10.5194/amt-10-1957-2017

Webb AR, Slaper H, Koepke P, Schmalwieser AW (2011) Know your standard: clarifying the CIE erythema action spectrum. Photochem. Photobiol 87:483-486. https://doi.org/10.1111/j.1751-1097.2010. 00871.x

Publisher's note Springer Nature remains neutral with regard to jurisdictional claims in published maps and institutional affiliations. 